\title{
Estimated Avian Nest Loss Associated with Oil and Gas Exploration and Extraction in the Western Canadian Sedimentary Basin
}

\section{Estimation de la perte de nids d'oiseaux attribuable à l'exploration et à l'exploitation pétrolière et gazière dans le bassin sédimentaire de l'Ouest canadien}

\author{
$\underline{\text { Steven L. Van Wilgenburg }}{ }^{1}, \underline{\text { Keith A. Hobson }}^{1}, \underline{\text { Erin M. Bayne }}^{2}$ and Nicola Koper $^{3}$
}

\begin{abstract}
Annual mortality within bird populations can be attributed to numerous sources; however, the extent to which anthropogenic sources of mortality contribute to avian demography is largely unknown. Quantifying the relative magnitude of human-related avian mortality could inform conservation efforts, particularly if multiple sources of human-related mortality can be contrasted. The unintentional destruction of nests and their contents by industrial activities conducted during the breeding season of resident and migratory birds presumably leads to one such source of human-caused avian mortality. As part of a broader effort to quantify major sources of human-related avian mortality, we estimated the magnitude of nest loss resulting from the terrestrial oil and gas sector in Canada, including: (1) seismic exploration, (2) pipeline right-of-way clearing, (3) well pad clearing, and (4) oil sands mining within the Western Canadian Sedimentary Basin (WCSB). We estimated nest losses as the product of estimated nest densities, the area disturbed annually, and the proportion of annual disturbance presumed to occur during the breeding season. The estimated number of nests disturbed annually by all oil and gas sectors combined ranged between $11,840-60,380$. Interannual variation in exploration and extraction, and uncertainty in nest densities and the proportion of the disturbances occurring during the breeding season contributed to the variation. Accounting for natural mortality suggests an estimated loss of 10,200 - 41,150 (range) potential recruits into the migratory bird population in a subsequent year. Although nest destruction is only one small component of the potential impacts of the oil and gas industry upon avian populations, these estimates establish a baseline for comparison with other sources of human-caused avian mortality. Models are now needed to compare nest losses against the legacy effects of oil and gas sector habitat disturbances and associated cumulative effects so that mitigation efforts can be prioritized.
\end{abstract}

RÉSUMÉ. Chez les populations d'oiseaux, la mortalité annuelle peut être attribuée à de nombreuses sources. Toutefois, on connait très peu l'importance qu'ont les sources de mortalité d'origine anthropique sur la démographie aviaire. La détermination de l'ampleur relative de la mortalité aviaire d'origine anthropique permettrait d'orienter les efforts de conservation, particulièrement si différentes sources de mortalité peuvent être mises en contraste. La destruction non intentionnelle de nids et de leur contenu par des activités industrielles menées durant la saison de nidification des oiseaux résidents et migrateurs correspond vraisemblablement à ce genre de source de mortalité aviaire d'origine anthropique. Dans le cadre d'un vaste effort destiné à quantifier les sources principales de mortalité aviaire d'origine anthropique, nous avons estimé l'ampleur de la perte de nids résultant de l'activité industrielle terrestre liée au pétrole et au gaz au Canada, dont : 1) la prospection sismique; 2) le défrichement d'emprises de pipelines; 3) le défrichement de plateformes d'exploitation; et 4) l'exploitation des sables bitumineux dans le bassin sédimentaire de l'Ouest canadien. Nous avons estimé la perte de nids à partir d'estimations de densités de nids, de la superficie touchée annuellement et de la proportion du dérangement qui surviendrait durant la saison de nidification. L'estimation du nombre de nids touchés annuellement par tous les secteurs du pétrole et du gaz combinés s'échelonne de 11 840 à 60 380. L'écart entre ces deux valeurs est attribuable à la variation interannuelle de l'exploration et de l'exploitation, et à l'incertitude liée à la densité des nids et à la proportion du dérangement qui surviendrait durant la saison de nidification. En tenant compte de la mortalité naturelle, ce dérangement engendrerait une perte d'environ 10200 à 41150 recrues potentielles dans la population d'oiseaux migrateurs au cours de l'année suivante. Même si la destruction de nids ne représente qu'une petite partie des impacts potentiels de l'industrie pétrolière et gazière sur les populations aviaires, les estimations que nous présentons ici offrent une base de comparaison avec d'autres sources de mortalité aviaire d'origine anthropique. Il sera maintenant important

${ }^{1}$ Science \& Technology Branch, Environment Canada, ${ }^{2}$ Department of Biological Sciences, University of Alberta, ${ }^{3}$ Natural Resources Institute, University of Manitoba

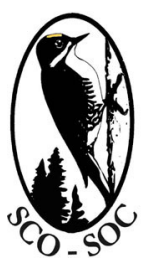

Sponsored by the Society of Canadian Ornithologists and Bird Studies Canada Parrainée par la Société des ornithologistes du Canada et Études d'oiseaux Canada

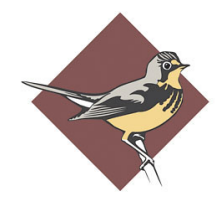

BIRD STUDIES CANADA 
de générer des modèles permettant de comparer les pertes de nids avec les répercussions futures des perturbations d'habitats imputables à l'activité pétrolière et gazière ainsi que leurs effets cumulatifs, afin que des mesures d'atténuation puissent être priorisées.

Key Words: adult recruitment; gas well; incidental take; migratory bird; mortality; nest loss; nests; oil and gas; oil sands; oil well; pipeline; seismic line

\section{INTRODUCTION}

The Western Canadian Sedimentary Basin (WCSB) contains one of the world's largest known deposits of hydrocarbons (Petroleum Resources Branch 2010). Although the oil and gas industry has operated in the WCSB since the early 20th century (Schneider et al. 2003), recent decades have seen a rapid increase in development (Copeland et al. 2011). In particular, high oil prices have made resources such as bitumen (oil sands) economically attractive, and both exploration and extraction of this resource has contributed substantially to the rapid expansion of the oil and gas sector within the WCSB (Tertzakian and Baynton 2011).

Potential impacts of oil and gas exploration and extraction on avian populations vary from habitat loss and fragmentation (Bayne et al. 2005, Machtans 2006), introduction of exotic/ invasive species (Cameron et al. 2007), and chronic industrial noise affecting pairing success and population age structure (Habib et al. 2007). Industrial activities associated with the oil and gas industry can also cause long-term changes in habitat supply and quality related to succession of disturbed habitats (Lee and Boutin 2006), mortality due to oil contamination in tailings ponds (Wells et al. 2008, Timoney and Ronconi 2010), and sublethal effects such as reduced nestling growth (Gurney et al. 2005), hormonal stress, and reduced nesting success (Wayland and Smits 2004, Gentes et al. 2006). In addition, oil and gas exploration and infrastructure development conducted during the breeding season could also result in the unintentional destruction of nests, eggs, nestlings, and/or adult migratory birds. The potential magnitude of nest-related mortality due to breeding season habitat disturbance remains unclear. Decreased recruitment caused by nest destruction is in addition to both natural and other anthropogenic sources of nest predation, mortality, and morbidity. If anthropogenic sources of avian mortality are additive to natural mortality, they could provide one target for management action for species requiring conservation efforts (Calvert et al. 2013). However, efficiently addressing additive mortality requires the ability to quantify and contrast various sources of humancaused avian mortality. Thus, a better understanding of the magnitude of mortality associated with nest destruction would be informative regarding which sources of direct avian mortality are of the greatest management concern (Calvert et al. 2013).

Our objective was to provide an estimate of nest loss due to the activities of the terrestrial oil and gas sector in Canada as part of a broader initiative to quantify anthropogenic sources of avian mortality as detailed in Calvert et al. (2013). We also provide a first estimate of the expected reductions in recruitment associated with this nest loss.

\section{METHODS}

Based on data from the Canadian Association of Petroleum Producers (hereafter CAPP), $96 \%$ of all exploratory drilling expenditures within Canada in 2008 were in the WCSB (Canadian Association of Petroleum Producers 2012). Therefore, we limited all analyses to the WCSB (Fig. 1). In addition, although there has been significant exploration activity in the Northwest Territories and Yukon, those territories have not had significant exploration in recent years, e.g., CAPP reports only nine wells drilled in NWT in 2009, and none in Yukon, therefore these regions were not considered in these analyses.

Fig. 1. Geographic distribution of the Western Canadian Sedimentary Basin (WCSB), and point-count sampling of grassland bird abundance (see Methods). Land cover derived from Latifovic et al. (2008).

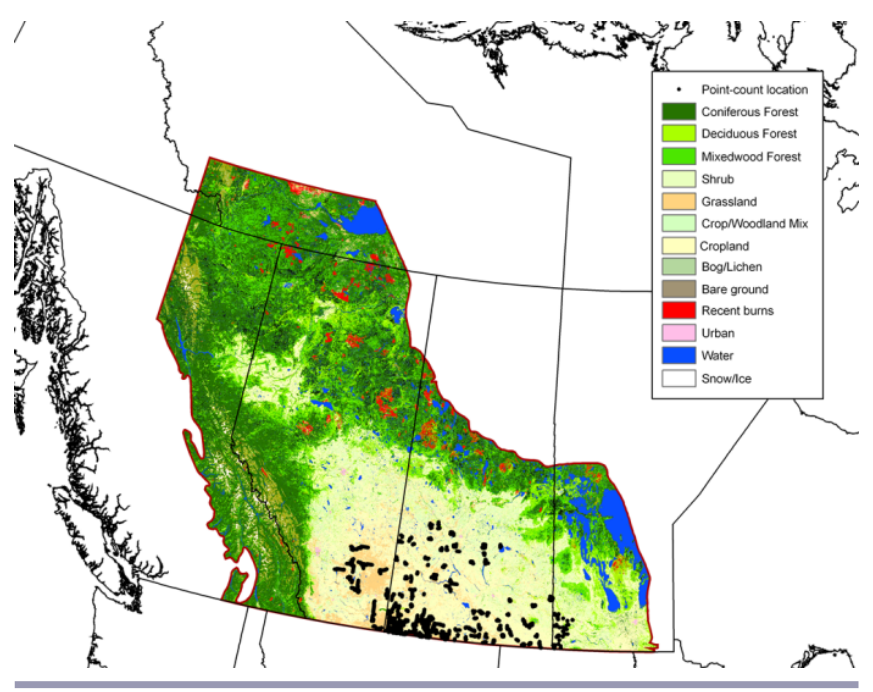

We estimated number of breeding bird territories based on available survey data and assumed that each territory represented a single breeding event. Annual nest loss was estimated as the product of bird densities and the area of breeding habitat estimated to be disturbed during the migratory bird breeding season (assuming May through July inclusively in boreal forest and April through July inclusively within the 
prairie region). Pairs or number of singing males during the breeding season were assumed to represent a nesting attempt. We assumed birds had one brood, i.e., 1 nest, per season.

\section{Estimating avian nest densities}

For boreal forest species, density estimates were acquired from data collated by the Boreal Avian Modeling project (hereafter BAM; Cumming et al. 2010). The BAM data currently consist of over 100,000 off-road point-counts from across boreal North America (Fig. 1 in Hobson et al. 2013). Point-count data in the BAM data set were collected using multiple techniques including variations in count duration (3 - 20 minutes), limited versus unlimited distance methods, and sample design (Matsuoka et al. 2012, Sólymos2013). Details on BAM and the additional statistical corrections that apply are available from the BAM website (http://www.borealbirds.ca).

Densities of grassland songbirds were estimated by collating point-count data for 4537 stations across 342 sites across the Canadian prairie provinces (Fig. 1). Songbird surveys were taken from studies conducted during May and June of 1994, 1999, and 2006 to 2009. Grassland songbird counts were collected during mornings with wind $<20 \mathrm{~km} / \mathrm{hr}$ and with no precipitation using point-counts of either five or six minutes in duration collected with limited distance (100 m radius) methods or with distance to observations directly estimated (Sutter et al. 2000, McMaster and Davis 2001, Bogard 2011, Ranellucci et al. 2012). All point-counts were conducted between $0.5 \mathrm{hrs}$ before sunrise until 10:00 AM, during which all birds seen or heard were recorded (Bibby et al. 2000).

We modeled avian abundance using either generalized linear models (GLM) or generalized linear mixed effects (GLMM) regression including province, land cover strata from the 2005 MODIS Land cover Classification of Canada (hereafter LCC05; Latifovic et al. 2008), and the interaction of province and strata as fixed effects. Within-site covariation was accounted for using random effects for site in GLMMs. In GLM models, the variance function was inversely weighted by the number of replicates within a site. Models were fit using Poisson or negative binomial models with a log-link function. Models for grassland birds also included latitude to account for declining abundance toward the northern edge of the species' range. Estimated marginal means were then used as estimates of bird abundance by habitat and province. Total counts of grassland birds were modeled directly rather than summing predicted counts across individual species models. All GLM analyses were conducted using R 2.15.1 (R Development Core Team 2012), whereas all GLMM modeling was conducted using PASW statistics v 19.0.0 (IBM Corporation, 2010, Chicago, IL, http://www-01.ibm.com/ software/analytics/spss/).

Predictions from our regression models represented predicted mean counts and had to be converted to densities by dividing by the area sampled by point-counts. Previous authors have used maximum detection distances (MDD) as the estimated radius over which species are detected; however, this method tends to substantially underestimate densities (Thogmartin et al. 2006, Thogmartin 2010, Matsuoka et al. 2012). Following the BAM approach (Matsuoka et al. 2012), we used binomial distance-sampling models to calculate the effective detection radius (EDR). EDR is similar to effective strip width from line-transect sampling, and approximates the distance over which all birds are effectively sampled with $100 \%$ accuracy because at this distance, as many birds are detected beyond the EDR as remain undetected within the EDR (Buckland et al. 2001). EDR was estimated using counts divided into detections of $\leq 50 \mathrm{~m}$ versus detections beyond $50 \mathrm{~m}$ from the observer, or $\leq 100 \mathrm{~m}$ versus detections beyond $100 \mathrm{~m}$ from the observer. Where there was a discrepancy between the two EDR calculations, the larger EDR estimate was used in subsequent calculations. For models of total bird counts (grassland species only), EDR was estimated as the abundance-weighted mean of each individual species EDR. In contrast, estimated total density of boreal forest birds (BAM) was calculated as the sum of estimated densities for each of the 72 species modeled.

Point-count data were never designed to collect density estimates and the above techniques have not yet been fully validated using more intensive survey methods. In contrast, intensive survey methods such as spot-mapping directly measure bird densities by mapping individual bird territories over multiple (10 - 12) visits to a defined plot, and are thus considered a "gold standard" for determining avian densities (e.g., see Toms et al. 2006). Thus, we also obtained spotmapping data derived from the Canadian Breeding Bird Census (hereafter CBBC) database (Kennedy et al. 1999). The CBBC database comprises 640 individual plots across Canada of varying sizes $(1-5260$ ha, mean $=39$ ha $)$ sampled over the interval of 1929 to 1993 . These data have the advantage of providing locally intensive and more accurate estimates of density, but the age of the data, the lack of replication, and small area sampled limit inference based upon these data (Kennedy et al. 1999). We therefore used density estimates from both point-counts and CBBC to provide upper and lower bounds upon our estimates of nest loss.

Densities were subsequently converted to weighted mean densities for the boreal forest and prairie ecozones by calculating the weighted means of the habitat-specific density estimates, from both CBBC and point-count derived estimates, for each ecozone within the portion of each province falling within the WCSB. Weights were calculated based upon the proportional area of the province/ecozone combination made up of the given land cover type.

\section{Estimating area disturbed by oil and gas operations}

We estimated the area of habitat disturbed within the annual migratory bird breeding season because this is the period 
during which eggs and nestlings could experience humancaused mortality. Data on the area of oil and gas associated habitat disturbances do not typically include data on the season in which disturbances were created. We therefore estimated annual area disturbed by seismic lines, pipelines, wells, and oil sands mining, respectively, and subsequently applied assumptions regarding the proportion of disturbance occurring during the breeding season. Thus, we used Geographic Information Systems (GIS) and statistical models to summarize or predict the annual area disturbed by seismic lines, pipelines, well sites, and oil sands mining, respectively (see Appendix 1 for data sources).

\section{Seismic lines}

Geo-referenced data for seismic lines are generally represented as line features having an associated length but no width, thus we used GIS buffer analyses to create polygons representing the area cleared for seismic surveys. Georeferenced data for British Columbia (Appendix 1) included right-of-way widths and thus buffer distances were based upon data in this field. Geo-referenced seismic line data for Alberta lacked a width field but included year of creation, thus GIS buffer widths were based upon data in the Alberta Sustainable Resources Department (SRD) Application Disposition Process and Tracking database (Appendix 1). Seismic lines created prior to 2005 were therefore buffered by $3 \mathrm{~m}$ per side (6 $\mathrm{m}$ wide), whereas seismic lines created after 2005 averaged $3.75 \mathrm{~m}$ wide, and thus buffers were created to $1.875 \mathrm{~m}$ on either side of the lines (Appendix 1). For both Alberta and British Columbia, the data contained dates, thus areas were calculated for individual years.

Saskatchewan and Manitoba both lacked geo-referenced data on seismic lines but did have geo-referenced well-site data. We therefore used data derived from Alberta to develop statistical models to predict the total area disturbed by seismic lines at a township scale. Data on well densities (wells $/ \mathrm{km}^{2}$ ) and area disturbed by seismic lines were obtained for townships within Alberta, and statistical relationships were then derived to estimate area disturbed (Appendix 2). For Saskatchewan, the geo-referenced well-site data included license year, and so we calculated the proportion of wells that were licensed within a township in a given year (1999 to 2009) and assumed that the proportion of the predicted cumulative "footprint" of seismic lines was proportional to the proportion of wells within a township that were licensed in a particular year (e.g., if 5\% of wells in a township were licensed in 2005, $5 \%$ of the cumulative footprint was assumed to have been created in 2005). A similar process was followed for Manitoba; however, geo-referenced well-site data did not include license year. Therefore, we used data on wells completed within Canada from 1981 to 2009 (http://www.capp.ca/library/ statistics/handbook/Pages/default.aspx\#ZlOMTGNAQG7x) to estimate the proportion of wells drilled within Manitoba for 1999 to 2009, respectively, and applied these proportions to township-level cumulative footprint estimates as an estimate of total annual activity.

The above analyses estimated annual area disturbed by seismic lines and not the area cleared during the breeding season relevant to our study. CAPP estimates that $\sim 1 \%$ of annual seismic line clearing occurs during the breeding season (CAPP, personal communication) and we used this as our assumed minimum proportion disturbed. We generated a high estimate of the proportion of disturbance based upon 20\% of seismic exploration occurring outside of winter (Ziff Energy Group 2003). We assumed that $\sim 25 \%$ of the remaining seismic exploration would occur during the breeding season, and thus a maximum of $5 \%(0.2 \times 0.25)$ of the annual area disturbed would be created during the breeding season.

\section{Pipelines}

Similar to seismic lines, pipelines are typically represented as line features. Geo-referenced pipeline data for British Columbia (Appendix 1) included right-of-way widths and thus buffer distances were based upon data in this field. Data from SRD Application Disposition Process and Tracking database suggested that the length weighted average pipeline width in Alberta was $20 \mathrm{~m}$. We therefore buffered pipeline features in Alberta by $10 \mathrm{~m}$ per side (Appendix 1). Date fields were used to assign disturbances to a given year and thus areas were calculated for individual years.

Geo-referenced pipeline data were also lacking for Saskatchewan and Manitoba. Thus, statistical models were developed to predict the total area disturbed by pipelines at a township scale based upon well-site densities (wells $/ \mathrm{km}^{2}$ ) and area disturbed by pipelines within Alberta (Appendix 2). License year within the Saskatchewan well data was used to calculate the proportion of wells that were licensed within a township in a given year (1999-2009) and we multiplied the predicted cumulative area disturbed by this proportion to estimate the proportion of clearing that occurred within a particular year. Because well data for Manitoba did not include license year, we used data on wells completed within Canada from 1981 to 2009 (http://www.capp.ca/library/statistics/ handbook/Pages/default.aspx\#Z1OMTGNAQG7x) to estimate the proportion of wells drilled within Manitoba for 1999-2009, respectively, and applied these proportions to township-level cumulative footprint estimates as an estimate of total annual activity.

Based on consultations with the Canadian Energy Pipeline Association (hereafter CEPA), we assumed that $1 \%$ of annual pipeline right-of-way clearing currently occurs during the breeding season. However, transportation lines and gathering lines, i.e., lines that collect hydrocarbons from well heads and link to larger networks, were not separated within the available data. Because wells are linked to the distribution network via gathering lines, and approximately $81 \%$ of pipelines are gathering lines, we also estimated area cleared for pipeline 
right-of-ways during the breeding season by applying the aforementioned range of annual well-drilling activity occurring during the breeding season, weighted by the proportion of lines that are gathering lines (Appendix 1).

\section{Wells}

Data on well sites were available for all four provinces included in our analysis (Appendix 1). Well locations are generally represented as point features and require buffer analyses to represent their area. Well pads are typically 1 ha in area $(100 \mathrm{~m} \times 100 \mathrm{~m})$. In addition, 1 ha is typically also disturbed in creating access to the well pad (CAPP, personal communication). Thus, we created square buffers 2 ha in size around all well sites to estimate the area disturbed. We assumed well license year, in data for Alberta, British Columbia, and Saskatchewan, represented the year of disturbance. For Manitoba, which lacked license year, we used data on well completions from 1981 to 2009 to estimate the proportion of the cumulative footprint that came from a given year.

Proportion of wells cleared during the breeding season was estimated using western Canada monthly well count data (http://www.caodc.ca/statistics/wellcounts wc monthly.html). From 1999 to 2009, these data suggest $17-21 \%$ of drilling occurred during the breeding season in the boreal ecozone, and $23-35 \%$ of drilling occurred during the breeding season in the prairie ecozone. However, there was a decline in drilling activity during the breeding season after 2004, and thus only estimates from 2005 to 2009 were used. For the boreal ecozone, we assumed a range of $14-18 \%$ of annual activity occurred during the breeding season and $21-27 \%$ for the prairie ecozone. These ranges are roughly consistent with data from satellite imagery for the Alberta foothills (Gaulton et al. 2011), which suggest $24 \%$ of wells were cleared during the breeding season (Alberta Innovates Technology Futures, unpublished data), and expert opinion provided by CAPP suggesting rates of $1-5 \%$ per month.

\section{Oil sands mining}

Data on area disturbed by oil sands mining was obtained from published sources (Latifovic et al. 2005, Gillanders et al. 2008, Timoney and Lee 2009). Annual area disturbed was estimated by fitting a nonlinear (sigmoidal) regression model of the form:

$$
\text { Cumulative area disturbed (ha) }=\frac{a}{1+e^{-\left(\frac{x-x_{0}}{b}\right)}}
$$

where $\mathrm{x}$ represents year. We applied this regression to data presented in Latifovic et al. (2005), and Gillanders et al. (2008), and Timoney and Lee (2009) including projected disturbance to 2050 . We then inferred annual rates (ha disturbed per year) for the years 1999 through 2010 as the difference between model predictions in year $\mathrm{N}_{\mathrm{t}}$ and year $\mathrm{N}_{\mathrm{t}-1}$.
Based on monthly well-count data, we assumed a minimum of $14 \%$ of annual clearing for oil sands occurs during the breeding season. The maximum proportion of clearing for oil sands mining was assumed to be $33 \%$, assuming no major changes in amount of mining throughout the year. Habitatspecific estimates were generated based on proportions of the mine areas occupied by specific habitats, e.g., dense conifer, open mixedwood, etc., as reported in Gillanders et al. (2008). No separate estimate was generated for oil sands steam assisted gravity drainage (SAGD) operations because data for this practice were included within the seismic line and well pad estimates.

\section{Estimating loss of nests and adult recruitment}

We estimated the distribution of nest losses associated with each sector using a Monte Carlo simulation approach to reflect uncertainties associated with our model parameters, i.e., nesting densities, area disturbed annually, proportion of disturbance occurring during the breeding season, and demographic parameters. We ran 50,000 simulations in which the area disturbed during the breeding season was estimated in each iteration by taking a random draw of our annual areadisturbed estimates using nonparametric bootstrap (n - 1) sampling and multiplying the mean of this draw by a random uniform number between the minimum- and maximumestimated proportion of habitat disturbance occurring during the breeding season (see Appendix 1 for summary of these proportions). Finally, the result of each iteration was multiplied by random uniform numbers between our minimum (mean CBBC estimate) and maximum (mean point-count derived estimate) bird density estimates (Table 1). For example, density of territories for boreal regions of Alberta would be a random uniform number falling between 2.7 and 5.3 birds/ha and would be multiplied by the area estimated to be disturbed in the breeding season in one of the 50,000 iterations (Table 1).

Because nest loss is not demographically equivalent to loss of adults, we took the additional step of applying a simple stochastic demographic model to estimate the potential impacts of habitat disturbance during the breeding season upon recruitment. Our Monte Carlo simulation followed a similar procedure as outlined in Hobson et al. (2013); however, our model was parameterized using disturbance estimates and assumptions as described herein (see results and Appendix 1 of this manuscript). We incorporated estimates of clutch size, nest survival, survival of young to independence, and estimated juvenile overwintering survival to estimate the number of recruits into the adult breeding population lost because of habitat disturbance. Demographic parameters were derived from the literature (see Appendix 4 of Hobson et al. 2013). We used the mean from a nonparametric bootstrap (n - 1) of the literature data for clutch size, nest success, and probability of survival to independence in our Monte Carlo simulation. Because we only found two estimates of juvenile 
overwintering survival probability in the literature, overwintering survival probability came from a random uniform distribution falling between these two values. Monte Carlo simulations were conducted in the $\mathrm{R}$ statistical computing environment v. 2.15.1 (R Development Core Team 2012) using scripts written by SVW.

Table 1. Weighted mean density estimates (birds/ha) derived by averaging habitat specific densities weighted by the area of habitat within the province and ecozone.

\begin{tabular}{lccc}
\hline \hline Province & Ecozone & $\begin{array}{c}\text { Canadian Breeding } \\
\text { Bird } \\
\text { Census Database }\end{array}$ & $\begin{array}{c}\text { Point-count } \\
\text { Derived Densities }\end{array}$ \\
\hline Alberta & Boreal & 2.7 & 5.3 \\
Alberta & Prairie & 1.0 & 2.0 \\
British & Boreal & 2.7 & 5.9 \\
Columbia & Boreal & 2.9 & 5.5 \\
Manitoba & Prairie & 1.2 & 1.4 \\
Manitoba & Boreal & 2.5 & 3.3 \\
Saskatchewan & Prairie & 0.8 & 1.8 \\
Saskatchewan & & & \\
\hline
\end{tabular}

Finally, we derived species-specific estimates of the number of recruits lost for focal species from both the grassland and boreal biomes to examine variation in lost recruitment between species. We selected focal species based on habitat specialization, conservation concern, and potential to make comparison with estimates from other industrial sectors. Thus, we generated species-specific estimates for Spraque's Pipit (Anthus spragueii), Western Meadowlark (Sturnella neglecta), Canada Warbler (Cardellina canadensis), and Ovenbird (Seiurus aurocapilla). We derived species specific nest density estimates from the aforementioned point-count data using the same regression methods mentioned above. Because estimates of demographic parameters for these species are sparse, we used bootstrapping of the multispecies estimates provided in Appendix 3 of Hobson et al. (2013) as done above in lieu of species-specific estimates for parameters such as nest success, fledging success, and survivorship.

\section{RESULTS}

\section{Estimated densities}

Weighted mean bird densities calculated from spot-mapping (CBBC) versus point-count derived density estimates differed substantially (Table 1). Point-count derived density estimates were on average $\sim 1.8$ times greater than spot mapping estimates (Table 1). Regardless of these differences, both methodologies generally suggest that bird densities were lower in the prairie ecozone compared with the boreal forest.

\section{Estimated disturbance rates}

Estimates of annual area disturbed varied between provinces (Table 2). Annual area disturbed was generally highest in Alberta and lowest in Manitoba (Table 2). High interannual variability led to wide ranges in estimates of area disturbed by seismic lines, pipelines and well sites, respectively (Table 2). In the boreal forest of Alberta, for example, area disturbed by seismic lines ranged from a low of 1968 ha in 2000, to a high of 66,238 ha in 2003 , with a mean of 16,623 ha disturbed annually (Table 2).

The footprint of oil sands mining operations has grown since 1967 but the rate of growth is projected to slow as the area of bitumen sufficiently shallow to mine is developed (Fig. 2). Using the regression parameter estimates to predict cumulative footprint in each year from 1998 to 2010 resulted in an estimated average annual area disturbed of 3021 ha year per year between 1999 and 2009. Accounting for uncertainty

Table 2. Estimated annual area disturbed (hectares) by seismic lines, pipeline, and well sites by province. Estimates for Alberta and British Columbia resulted from analysis of georeferenced data in a Geographic Information System, whereas estimates for Saskatchewan and Manitoba result from a combination of GIS analyses and statistical relationships with well densities (see Methods and Appendix 1). Multiple years of estimates were generated (AB: 1999-2008; BC seismic 2003-2010; BC pipelines 2001-2008; BC well sites 1999-2010; SK 1999-2009; MB 1999-2009) and thus Low, Mean, and High correspond to summary statistics across years.

\begin{tabular}{|c|c|c|c|c|}
\hline Province & & $\begin{array}{l}\text { Seismic Lines } \\
\text { (ha) }\end{array}$ & $\begin{array}{l}\text { Pipelines } \\
\text { (ha) }\end{array}$ & $\begin{array}{c}\text { Well Sites } \\
\text { (ha) }\end{array}$ \\
\hline \multicolumn{5}{|l|}{ Alberta } \\
\hline \multirow{3}{*}{ Boreal } & Low & 1968 & 2946 & 6008 \\
\hline & Mean & 16,623 & 15,644 & 8752 \\
\hline & High & 66,238 & 34,995 & 11,088 \\
\hline \multirow{3}{*}{ Prairie } & Low & 106 & 22 & 8188 \\
\hline & Mean & 3503 & 19,458 & 11,096 \\
\hline & High & 23,865 & 68,996 & 14,176 \\
\hline \multicolumn{5}{|c|}{ British Columbia } \\
\hline \multirow{3}{*}{ Boreal } & Low & 76 & 2 & 956 \\
\hline & Mean & 2136 & 1066 & 2094 \\
\hline & High & 5361 & 2312 & 3042 \\
\hline \multicolumn{5}{|l|}{ Manitoba } \\
\hline \multirow{3}{*}{ Boreal } & Low & 91 & 4 & 2 \\
\hline & Mean & 443 & 22 & 8 \\
\hline & High & 1078 & 53 & 20 \\
\hline \multirow{3}{*}{ Prairie } & Low & 22 & 39 & 80 \\
\hline & Mean & 106 & 190 & 392 \\
\hline & High & 259 & 464 & 954 \\
\hline \multicolumn{5}{|c|}{ Saskatchewan } \\
\hline \multirow{3}{*}{ Boreal } & Low & 716 & 57 & 154 \\
\hline & Mean & 1202 & 95 & 345 \\
\hline & High & 1407 & 111 & 476 \\
\hline \multirow{3}{*}{ Prairie } & Low & 369 & 1222 & 1900 \\
\hline & Mean & 619 & 2053 & 6064 \\
\hline & High & 725 & 2403 & 7776 \\
\hline
\end{tabular}


Table 3. Estimated numbers of bird nests lost annually because of pipeline, seismic line, and well site construction during the migratory bird breeding season for the boreal and prairie ecozones within the Western Canadian Sedimentary Basin. Estimates represent percentiles of 50,000 Monte Carlo simulations incorporating variance associated with differing assumptions regarding amount and timing of disturbance relative to the breeding season, nest densities, and interannual variation in industrial activity (see Methods).

\begin{tabular}{|c|c|c|c|c|c|c|c|c|c|c|c|}
\hline \multirow[b]{2}{*}{ Province } & & \multicolumn{5}{|c|}{ Boreal Ecozone } & \multicolumn{5}{|c|}{ Prairie Ecozone } \\
\hline & & 5th & 25th & Median & 75th & 95 th & 5 th & 25 th & Median & 75th & 95th \\
\hline \multicolumn{12}{|l|}{ Seismic } \\
\hline Alberta & & 437 & 969 & 1677 & 2881 & 5637 & 26 & 71 & 129 & 218 & 383 \\
\hline British Columbia & & 45 & 135 & 233 & 376 & 648 & $\mathrm{n} / \mathrm{a}$ & $\mathrm{n} / \mathrm{a}$ & $\mathrm{n} / \mathrm{a}$ & $\mathrm{n} / \mathrm{a}$ & $\mathrm{n} / \mathrm{a}$ \\
\hline Manitoba & & 15 & 30 & 48 & 74 & 120 & 1 & 2 & 4 & 6 & 9 \\
\hline Saskatchewan & & 41 & 69 & 103 & 138 & 177 & 9 & 15 & 23 & 32 & 45 \\
\hline & Total & 822 & 1403 & 2122 & 3328 & 6090 & 53 & 99 & 158 & 247 & 413 \\
\hline \multicolumn{12}{|l|}{ Pipelines } \\
\hline Alberta & & 793 & 2146 & 4057 & 6802 & 11,772 & 84 & 542 & 1629 & 3315 & 6717 \\
\hline British Columbia & & 7 & 125 & 288 & 512 & 963 & $\mathrm{n} / \mathrm{a}$ & $\mathrm{n} / \mathrm{a}$ & $\mathrm{n} / \mathrm{a}$ & $\mathrm{n} / \mathrm{a}$ & $\mathrm{n} / \mathrm{a}$ \\
\hline Manitoba & & 1 & 3 & 6 & 10 & 17 & 3 & 9 & 17 & 27 & 44 \\
\hline Saskatchewan & & 5 & 12 & 21 & 30 & 40 & 42 & 110 & 195 & 290 & 429 \\
\hline & Total & 1128 & 2547 & 4445 & 7206 & 12,169 & 281 & 773 & 1869 & 3547 & 6948 \\
\hline \multicolumn{12}{|l|}{ Wells } \\
\hline Alberta & & 3704 & 4623 & 5523 & 6497 & 7769 & 2546 & 3247 & 3919 & 4675 & 5718 \\
\hline British Columbia & & 832 & 1121 & 1397 & 1720 & 2195 & $\mathrm{n} / \mathrm{a}$ & $\mathrm{n} / \mathrm{a}$ & $\mathrm{n} / \mathrm{a}$ & $\mathrm{n} / \mathrm{a}$ & $\mathrm{n} / \mathrm{a}$ \\
\hline Manitoba & & 67 & 113 & 157 & 211 & 303 & 20 & 34 & 45 & 59 & 80 \\
\hline Saskatchewan & & 106 & 137 & 160 & 183 & 216 & 1097 & 1483 & 1856 & 2280 & 2819 \\
\hline & Total & 5327 & 6366 & 7301 & 8297 & 9662 & 4215 & 5218 & 5881 & 6696 & 7860 \\
\hline
\end{tabular}

associated with both interannual variation and the assumption of $14-33 \%$ of disturbance occurring during the breeding season, we estimated that approximately $378-1056$ ha of boreal forest in Alberta are disturbed per year during the breeding season by oil sands mining.

\section{Estimated impact on nest loss and recruitment}

The median estimate of the total number of nests disturbed annually by all oil and gas sectors in both the boreal and prairie ecozones was 25,904 (range 11,840 - 60,380), with $90 \%$ of the estimates falling between 18,409 - 39,496 (Fig. 3A). Accounting for natural mortality suggests a median estimate of 20,005 (range 10,200 - 41,150) individuals, with $90 \%$ of the distribution falling between 14,957 - 27,539 (Fig. 3B).

Estimated nest loss (Table 3) and lost recruitment (Table 4) were generally highest for Alberta, and lowest in the boreal ecozone of Manitoba (Tables 3 and 4). In addition, estimated loss of nests and recruitment tended to be higher in the boreal plain ecozone than the prairie ecozone for most political jurisdictions, with the chief exception being Saskatchewan, where wells and pipelines were estimated to have a greater impact in the prairie ecozone than the boreal (Tables 3 and 4).

Owing in part to interannual variation in disturbance rates (Table 2), the breadth of estimates differed between sectors (Tables 3 and 5, Fig. 4 A-D). The highest level of nest loss
Fig. 2. Growth of the oil sands mining "footprint" in the Athabasca region since 1967. Data are derived from Latifovic et al. (2005), Gillanders et al. (2008), and Timoney and Lee (2009).

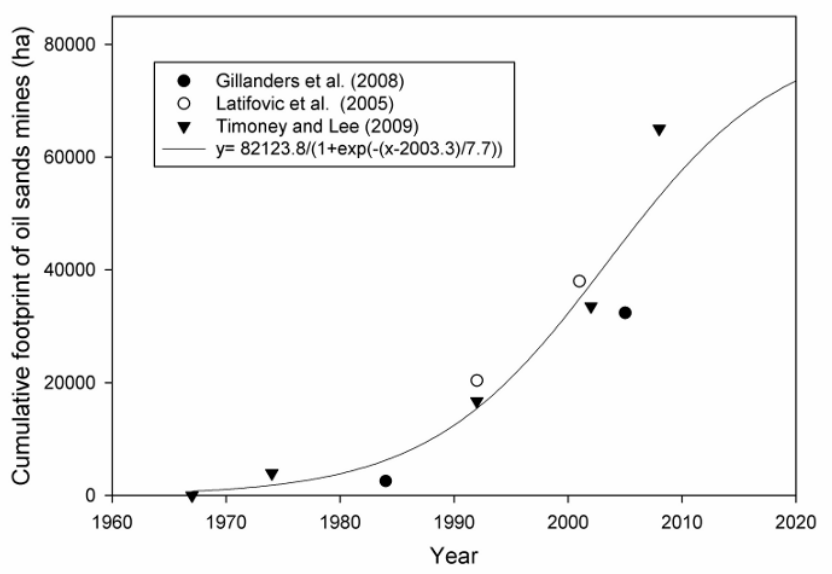

was associated with clearing of well pads (median $=13,260$, 5th -95 th percentiles $=10,550-16,265)$, followed by clearing for pipeline right-of-ways (median $=7066,5$ th -95 th percentile $=2318-15,612)$, and seismic lines $($ median $=2,312$, 5th -95 th percentiles $=989-6,277)$. Estimates of lost 
Table 4. Estimated lost recruitment into year ${ }_{t+1}$ because of pipeline, seismic line, and well site construction during the migratory bird breeding season for the boreal and prairie ecozones within the Western Canadian Sedimentary Basin. Estimates were derived from Monte Carlo simulations incorporating variance associated with differing assumptions regarding amount and timing of disturbance relative to the breeding season, nest densities, and interannual variation in industrial activity (see Methods).

\begin{tabular}{|c|c|c|c|c|c|c|c|c|c|c|}
\hline \multirow[b]{2}{*}{ Province } & \multicolumn{5}{|c|}{ Boreal Ecozone } & \multicolumn{5}{|c|}{ Prairie Ecozone } \\
\hline & 5th & 25th & Median & 75th & 95th & 5 th & 25 th & Median & 75th & 95th \\
\hline \multicolumn{11}{|l|}{ Seismic } \\
\hline Alberta & 365 & 833 & 1452 & 2509 & 5065 & 19 & 52 & 96 & 163 & 295 \\
\hline British Columbia & 38 & 116 & 201 & 327 & 580 & $\mathrm{n} / \mathrm{a}$ & $\mathrm{n} / \mathrm{a}$ & $\mathrm{n} / \mathrm{a}$ & $\mathrm{n} / \mathrm{a}$ & $\mathrm{n} / \mathrm{a}$ \\
\hline Manitoba & 13 & 26 & 42 & 65 & 109 & 1 & 2 & 3 & 4 & 7 \\
\hline Saskatchewan & 39 & 59 & 88 & 120 & 163 & 6 & 11 & 17 & 24 & 35 \\
\hline Total & 699 & 1213 & 1848 & 2901 & 5436 & 30 & 74 & 118 & 185 & 319 \\
\hline \multicolumn{11}{|l|}{ Pipelines } \\
\hline Alberta & 572 & 1585 & 3012 & 5038 & 8881 & 61 & 400 & 1219 & 2478 & 5034 \\
\hline British Columbia & 6 & 91 & 215 & 381 & 730 & $\mathrm{n} / \mathrm{a}$ & $\mathrm{n} / \mathrm{a}$ & $\mathrm{n} / \mathrm{a}$ & $\mathrm{n} / \mathrm{a}$ & $\mathrm{n} / \mathrm{a}$ \\
\hline Manitoba & 1 & 2 & 3 & 7 & 13 & 3 & 7 & 12 & 20 & 33 \\
\hline Saskatchewan & 3 & 9 & 16 & 23 & 31 & 31 & 82 & 144 & 215 & 325 \\
\hline Total & 833 & 1882 & 3299 & 5335 & 9156 & 208 & 577 & 1388 & 2651 & 5219 \\
\hline \multicolumn{11}{|l|}{ Wells } \\
\hline Alberta & 2613 & 3385 & 4100 & 4917 & 6171 & 1789 & 2372 & 2913 & 3522 & 4498 \\
\hline British Columbia & 593 & 826 & 1044 & 1298 & 1714 & $\mathrm{n} / \mathrm{a}$ & $\mathrm{n} / \mathrm{a}$ & $\mathrm{n} / \mathrm{a}$ & $\mathrm{n} / \mathrm{a}$ & $\mathrm{n} / \mathrm{a}$ \\
\hline Manitoba & 49 & 83 & 118 & 160 & 235 & 14 & 24 & 34 & 44 & 62 \\
\hline Saskatchewan & 75 & 99 & 118 & 139 & 171 & 780 & 1089 & 1379 & 1716 & 2210 \\
\hline Total & 3835 & 4691 & 5441 & 6280 & 7579 & 3038 & 3771 & 4374 & 5056 & 6132 \\
\hline
\end{tabular}

Fig. 3. Distribution of estimated A) number of nests, and B) recruitment into the bird population lost because of breeding season disturbances by all oil and gas industry sectors combined. Estimates were generated from Monte Carlo simulations including estimates of annual area disturbed, proportion of disturbances occurring during the breeding season, and estimated nest densities, plus demographic parameters derived from the literature (see Methods).
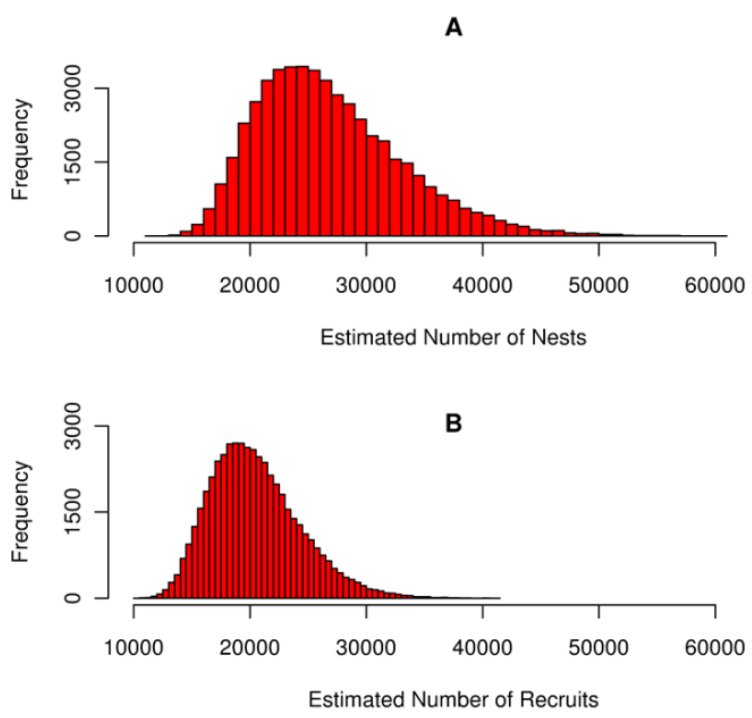

recruitment were slightly lower than those of nest loss, but following in the same order of impact: well pads (median = 9904,5 th -95 th percentiles $=7700-12,569$ ), followed by clearing for pipeline right-of-ways $($ median $=5242,5$ th -95 th percentile $=1714-11,846)$, and seismic lines $($ median $=1992$, 5th -95 th percentiles $=824-5576$ ). The estimated of loss of nests and recruitment associated with oil sands mining (Table 5) fell between those of pipelines and seismic lines (Tables 3 and 4).

\section{Magnitude of recruit loss for focal species}

Monte Carlo simulations suggested that oil and gas related habitat disturbances on the prairies result in 336 - 775 (5th 95th percentiles) potential Spraque's Pipit recruits being lost annually (median $=482$ ). Similarly, lost recruitment of Western Meadowlarks was $384-891$ birds based upon the 5 th - 95th percentiles (median $=550$ ). The estimated reduction of recruitment for forest associated species was of a similar magnitude as for Sprague's Pipit and Western Meadowlark, though higher for the more abundant species. Because Canada Warblers have relatively low densities, disturbance resulted in low estimates of recruits lost (median $=74,5$ th -95 th percentiles $=52-107$ ). Estimates were higher for the abundant Ovenbird, with $90 \%$ of the estimates falling between 498 1115 recruits per year $($ median $=730)$.

\section{DISCUSSION}

Ours is the first estimate of nest loss and associated reductions in potential recruitment for terrestrial oil and gas operations in Canada. The estimated range of nest loss due to terrestrial 
Fig. 4. Distribution of estimated number of nests disturbed annually by A) seismic lines, B) pipeline rightof-ways, C) wells, and D) oil sands mining; note differing scale of axes. Estimates were generated from Monte Carlo simulations including estimates of annual area disturbed, proportion of disturbances occurring during the breeding season, and estimated nest densities (see Methods).

A

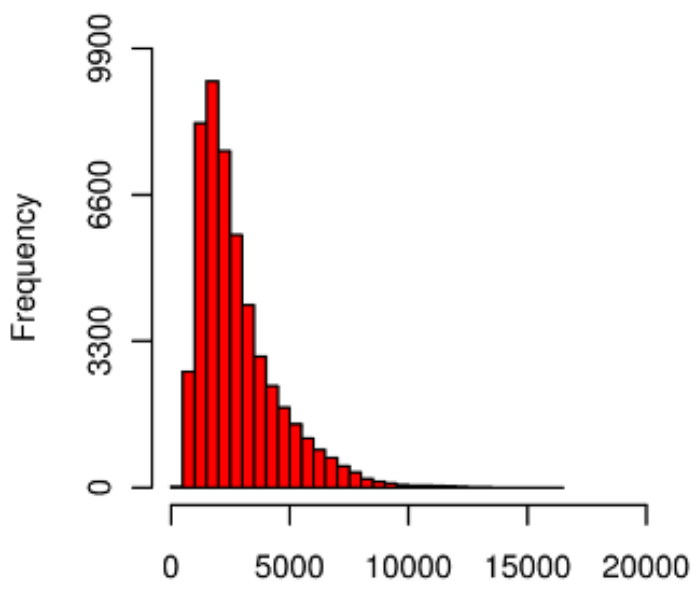

C

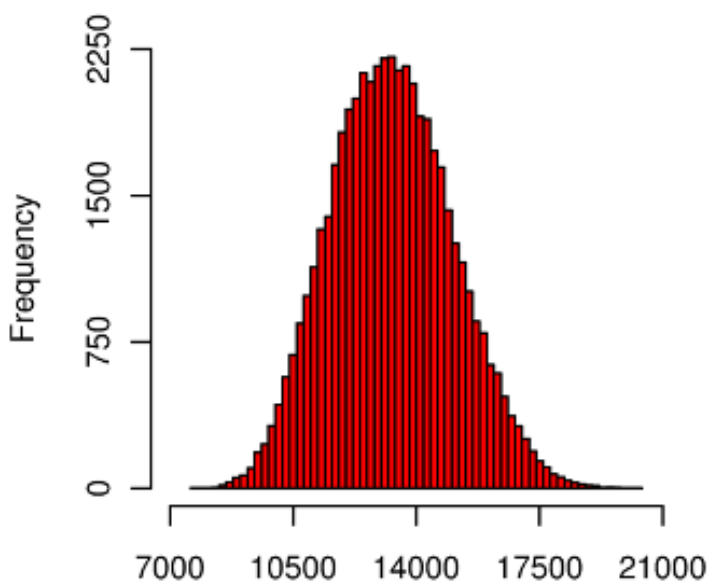

B

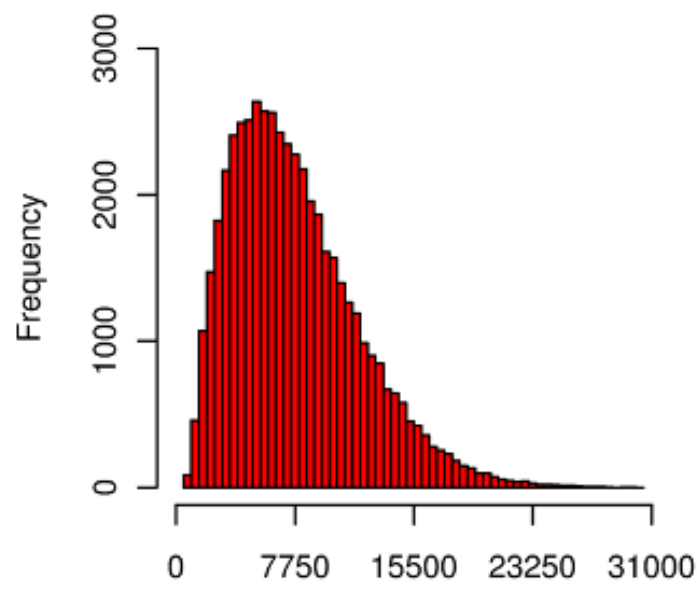

D

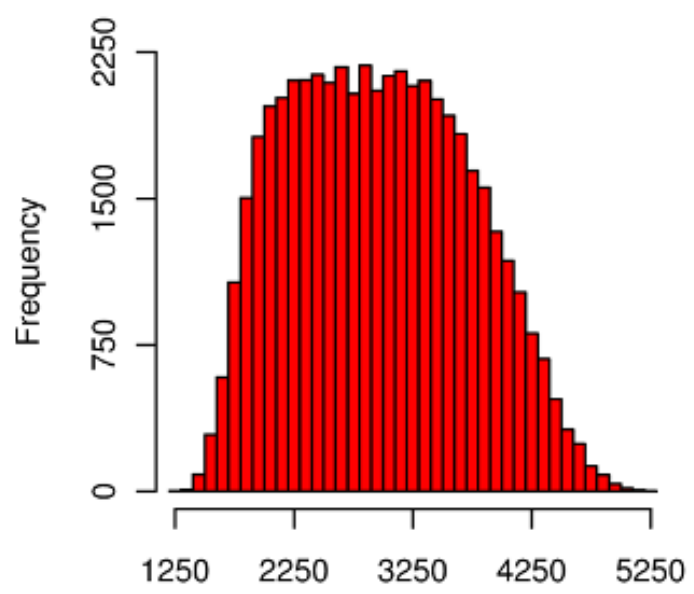

oil and gas exploration and extraction (i.e., 11,840 - 60,380 nest per year, corresponding to $10,200-41,150$ potential recruits) falls within previously reported ranges for anthropogenic sources of avian mortality. The range of estimates we provide for nest loss and potential lost recruitment associated with oil sands mining fall within the range of estimated mortality associated with oil sands tailings ponds (458 to 5029 birds), provided by Timoney and Ronconi (2010). To our knowledge however, no previous estimate has been generated for clearing activities associated with the seismic lines, pipelines, wells, or oil sands mining. Although we have provided an estimate of potential recruitment losses associated with the oil and gas industry habitat clearing, the exact demographic impact of these potential losses remains uncertain, especially in light of multiple overlapping land use changes occurring on the same land base (Schneider et al. 2003, Aumann et al. 2007), and the potential cumulative impacts of habitat change on carrying capacity through time. Thus, future efforts should be directed toward examining the demographic impact associated with these potential losses to recruitment in a cumulative effects context. 
Table 5. Estimated annual nests and recruitment into year ${ }_{t+1}$ lost because of oil sands mining operations in the Athabasca oil sands region. Estimates were generated based upon Monte Carlo simulations using a model combining estimated areas disturbed, estimated nesting densities and demographic parameters from the literature (see Methods).

\begin{tabular}{|c|c|c|c|c|c|}
\hline \multirow[b]{2}{*}{ Habitat } & \multicolumn{5}{|c|}{ Percentile } \\
\hline & 5 th & 25 th & Median & 75 th & 95th \\
\hline \multicolumn{6}{|l|}{ Nests } \\
\hline Dense Conifer & 186 & 314 & 460 & 633 & 892 \\
\hline Deciduous & 161 & 207 & 260 & 313 & 376 \\
\hline Wetland Shrub & 195 & 256 & 320 & 388 & 478 \\
\hline Closed Mixedwood & 1059 & 1376 & 1722 & 2080 & 2543 \\
\hline Open Mixedwood & 76 & 109 & 139 & 178 & 236 \\
\hline Total & 1833 & 2349 & 2939 & 3540 & 4235 \\
\hline \multicolumn{6}{|l|}{ Recruitment } \\
\hline Dense Conifer & 135 & 232 & 340 & 474 & 684 \\
\hline Deciduous & 114 & 152 & 192 & 235 & 296 \\
\hline Wetland Shrub & 139 & 188 & 237 & 292 & 374 \\
\hline Closed Mixedwood & 753 & 1009 & 1271 & 1567 & 2003 \\
\hline Open Mixedwood & 55 & 80 & 104 & 134 & 183 \\
\hline Total & 1424 & 1814 & 2193 & 2599 & 3137 \\
\hline
\end{tabular}

Although we estimated potential direct losses to adult recruitment associated with habitat clearing, we did not examine the potential demographic impacts associated with changes in net habitat supply that may result from habitat disturbances, which likely represent a net change in carrying capacity for avian populations. For example, using the mean annual disturbance rates we report for each sector (Table 3) and density estimates reported in Table 2, a crude estimate of the reduction in carrying capacity that has occurred within the WCSB in recent years is 180,590 - 357,550 territories per year, or roughly $6-15$ times greater than the number of nests estimated to be disturbed annually. Thus we have only addressed one small component of the potential demographic impacts of oil and gas exploration and extraction upon avian populations. The legacy effect of disturbed habitats and their associated cumulative effects may be a particularly important consideration because many of the habitat disturbances associated with the industry might not regenerate to original habitat conditions. As an example, approximately $65 \%$ of seismic lines in the boreal plains of Alberta remain dominated by grasses and forbs more than 35 years after the initial disturbance (Lee and Boutin 2006). In addition, portions of pipeline right-of-ways must be kept free of tree and shrub cover for pipeline maintenance and health and safety concerns, and we currently have no estimates of nest loss associated with this activity. Furthermore, Gillanders et al. (2008) projected that 81,000 ha of land will be cleared for oil sands mining activities in the Athabasca region. Given the current pace of reclamation and uncertainty with regard to habitat characteristics into the future, changes in habitat supply likely represents an important consideration in the assessment of avian demography. Thus our crude estimate of reduction in carrying capacity may represent an underestimate of the cumulative reductions in carrying capacity that could occur in the WCSB through time. Future efforts to assess the demographic consequences of anthropogenic sources of mortality should contrast the biological importance of nest loss versus cumulative changes in carrying capacity through habitat supply modeling coupled with projections of avian abundance.

Exploration activity in the oil patch is highly variable among years. In general, exploration activity has increased, but shows marked interannual variation. For example, the number of wells drilled annually within the WCSB in 1981 was just under 7000 wells, and subsequently increased to just under 27,000 wells in 2005. By 2009, however, this number decreased to just 9933 wells in the wake of the economic crisis of 2008. This level of variability highlights the importance of incorporating interannual variation into estimates of nest destruction. Estimates we generated using the same density estimates and assumptions regarding proportion of disturbance occurring during the breeding season varied 2 to 72 fold for a given sector simply by incorporating low and high estimates of annual area disturbed from multiple years of data (S. L. Van Wilgenburg, unpublished data). In addition, the trend toward increased exploration to find diminishing reserves suggests that either some form of projection (forecast), or future reassessment of nest losses associated with the oil and gas sector would be useful because current estimates likely do not apply to future scenarios/impacts and are likely only representative of current conditions and should not be used to project future impacts. This may be an important consideration for regions that have thus far had little exploration and development, e.g., Yukon and Northwest Territories, because there may be additional nest losses associated with road construction (etc.) required to develop 
the resource. Furthermore, we have not addressed potential demographic losses associated with road construction and maintenance directly associated with the oil and gas industry beyond those associated with well pad access. These roads are not easily distinguished from the broader road network in existing databases and so were not included here except those for direct well pad access. Additionally, our estimates do not incorporate nest losses potentially associated with pipeline maintenance, i.e., clearing trees and shrubs, because we currently have no estimates of disturbance rates for this activity.

Although incorporating a broad range of disturbance estimates and avian densities increased the likelihood that our estimates bound the "true" value, there is substantial room for improvement. Precision could be improved if multiyear, season-specific disturbance data could be collected, particularly covering the breeding season period. This could be accomplished most effectively using satellite imagery, as has previously been done to estimate rates of change in oil sands mining operations (Gillanders et al. 2008, Timoney and Lee 2009). In addition, reasonably large differences in densities estimated from spot mapping versus point-count derived data greatly reduced the precision of our estimates. These differences could be due to relatively low sample sizes in the CBBC spot-mapping data set, inaccuracies in distance estimation for point-count data, biased sampling in either data set, or numerous other statistical and methodological issues. In particular, few samples were located in crop, thus densities may be biased upward. In addition, many of the spot mapping grids within the CBBC date back to the mid-1960s and 1970s (Kennedy et al. 1999), so estimates may be biased either low or high relative to current densities simply because of population changes over the intervening decades. Furthermore, our assumption of a single breeding attempt, and inability to account for nest initiation dates (etc.) in relation to exact timing of disturbances could result in upward bias of our estimates. However, our use of densities derived from both spot-mapping and point-counts, combined with our simple demographic model to account for some nests potentially failing prior to the occurrence of a disturbance suggest that our estimates likely bound the true value. A system of wellstratified spot-mapping grids and point-count stations across the WCSB would improve precision and aid in assessing methods of converting point-count data to densities. Furthermore, spot-mapping, nest monitoring and markrecapture work in a before-and-after-control-impact (BACI) design study in areas slated for clearing would directly inform our understanding of the local demographic impacts of habitat disturbance on avian populations. However, the direct impacts at a local scale clearly need to be placed in the broader context of the cumulative spatial and temporal impacts of the industry on bird populations. Better estimates of the aforementioned parameters should be used to model the cumulative impacts of the oil and gas sector on avian populations through space and time so that mitigation efforts can refined and implemented.

Responses to this article can be read online at: http://www.ace-eco.org/issues/responses.php/585

\section{Acknowledgments:}

We are grateful to Jared Kyllo and Daiyuan Pan for their help in conducting most of the GIS analyses, and Jim Schieck for arranging analyses of the Alberta data. Stephen Davis, Ryan Fisher, Brenda Dale, and Matthew Giovanni graciously shared data on grassland bird abundance and expert opinion input on estimated EDRs. The Boreal Avian Modelling (BAM) Project is an international research collaboration for the ecology, management, and conservation of boreal birds. We acknowledge the BAM Project funding and data partners, and Technical Committee members who made this project possible. A list of participants in BAM can be found at www.borealbirds. ca. For their assistance in helping us to address assumptions with regard to seasonality of habitat disturbances, we thank the Canadian Association of Petroleum Producers and the Canadian Energy Pipeline Association (CEPA); particularly Tyler Colberg, Karen Etherington Piro, and John Masterson. Thanks to Craig Machtans for help with numerous aspects of this exercise. Finally, thank you to Paul Smith and two anonymous reviewers for providing many valuable comments that greatly improved the manuscript.

\section{LITERATURE CITED}

Aumann, C., D. R. Farr, and S. Boutin. 2007. Multiple use, overlapping tenures, and the challenge of sustainable forestry in Alberta. Forestry Chronicle 83:642-650.

Bayne, E. M., S. Van Wilgenburg, S. Boutin, and K. A. Hobson. 2005. Modeling and field-testing of Ovenbird (Seiurus aurocapillus) responses to boreal forest dissection by energy sector development at multiple spatial scales. Landscape Ecology 20:203-216. http://dx.doi.org/10.1007/ s10980-004-2265-9

Bibby, C. J., N. D., Burgess, D. A. Hill, and S. H. Mustoe. 2000. Bird census techniques. Second edition. Academic Press, London, UK.

Bogard, H. J. K. 2011. Natural gas development and grassland songbird abundance in southwestern Saskatchewan: the impact of gas wells and cumulative disturbance. Thesis. University of Regina, Regina, Saskatchewan, Canada.

Buckland, S. T., D. R. Anderson, K. P. Burnham, J. L. Laake, D. L. Borchers, and L. Thomas. 2001. Introduction of distance 
sampling: estimating abundance of biological populations. Oxford University Press, Oxford, UK.

Calvert, A. M., C. A. Bishop, R. D. Elliot, E. A. Krebs, T. M. Kydd, C. S. Machtans, and G. J. Robertson. 2013. A synthesis of human-related avian mortality in Canada. Avian Conservation and Ecology 8(2): 11. http://dx.doi.org/10.5751/ ACE-00581-080211

Cameron, E. K., E. M. Bayne, and M. J. Clapperton. 2007. Human-facilitated invasion of exotic earthworms into northern boreal forests. Ecoscience 14:482-490. http://dx.doi. org/10.2980/1195-6860(2007)14[482:HIOEEI]2.0.CO;2

Canadian Association of Petroleum Producers. 2012. CAPP statistical handbook. Canadian Association of Petroleum Producers, Calgary, Alberta, Canada. http://www.capp.ca/ library/statistics/handbook/Pages/default.aspx

Copeland, H. E., A. Pocewicz, and J. M. Kiesecker. 2011. Geography of energy development in western North America: potential impacts on terrestrial ecosystems. Pages 7-22 in D. E. Naugle, editor. Energy development and wildlife conservation in Western North America. Island Press, Washington, D.C., USA. http://dx.doi.org/10.5822/978-1-61091-022-4 2

Cumming, S. G., K. Lefevre, E. Bayne, T. Fontaine, F. K. A. Schmiegelow, and S. J. Song. 2010. Toward conservation of Canada's boreal forest avifauna: design and application of ecological models at continental extents. Avian Conservation and Ecology 5(2): 8. http://dx.doi.org/10.5751/ACE-00406-050208

Gaulton, R., T. Hilker, M. A. Wulder, N. C. Coops, and G. Stenhouse. 2011. Characterizing stand replacing disturbance in western Alberta grizzly bear habitat, using a satellitederived high temporal and spatial resolution change sequence. Forest Ecology and Management 261:865-877. http://dx.doi. org/10.1016/j.foreco.2010.12.020

Gentes, M.-L., C. Waldner, Z. Papp, and J. E. G. Smits. 2006. Effects of oil sands tailings compounds and harsh weather on mortality rates, growth and detoxification efforts in nestling tree swallows (Tachycineta bicolor). Environmental Pollution 142:24-33. http://dx.doi.org/10.1016/j.envpol.2005.09.013

Gillanders, S. N., N. C. Coops, M. A. Wulder, and N. R. Goodwin. 2008. Application of Landsat satellite imagery to monitor land-cover changes at the Athabasca Oil Sands, Alberta, Canada. Canadian Geographer 52:466-485. http:// dx.doi.org/10.1111/j.1541-0064.2008.00225.x

Gurney, K. E., T. D. Williams, J. E. Smits, M. Wayland, S. Trudeau, and L. I. Bendell-Young. 2005. Impact of oil-sands based wetlands on the growth of Mallard (Anas platyrhynchos) ducklings. Environmental Toxicology and Chemistry 24:457-463. http://dx.doi.org/10.1897/03-575.1
Habib, L., E. M. Bayne, and S. Boutin. 2007. Chronic industrial noise affects pairing success and age structure of Ovenbirds Seiurus auricapilla. Journal of Applied Ecology 44:176-184. http://dx.doi.org/10.1111/j.1365-2664.2006.01234. $\underline{\mathrm{X}}$

Hobson, K. A., A. G. Wilson, S. L. Van Wilgenburg, and E. M. Bayne. 2013. An estimate of nest loss in Canada due to industrial forestry operations. Avian Conservation and Ecology 8(2): 5. http://dx.doi.org/10.5751/ACE-00583-080205

Kennedy, J. L., P. Dilworth-Christie, and A. J. Erskine. 1999. The Canadian breeding bird (mapping) census database. Technical Report Series No. 342, Canadian Wildlife Service, Ottawa, Ontario.

Latifovic, R., K. Fytas, J. Chen, and J. Paraszczak. 2005. Assessing land cover change resulting from large surface mining development. International Journal of Applied Earth Observation and Geoinformation 7:29-48. http://dx.doi. org/10.1016/j.jag.2004.11.003

Latifovic, R., I. Olthof, D. Pouliot, and J. Beaubien. 2008. Land cover map of Canada 2005 at 250m spatial resolution. Natural Resources Canada/ESS/Canada Centre for Remote Sensing. Natural Resources Canada, Ottawa, Ontario, Canada. [online] URL: ftp://ftp.ccrs.nrcan.gc.ca/ad/NLCCLandCover/ LandcoverCanada2005 250m/

Lee, P., and S. Boutin. 2006. Persistence and development transition of wide seismic lines in the western Boreal Plains of Canada. Journal of Environmental Management 78:240-250. http://dx.doi.org/10.1016/j.jenvman.2005.03.016

Machtans, C. S. 2006. Songbird response to seismic lines in the western boreal forest: a manipulative experiment. Canadian Journal of Zoology 84:1421-1430. http://dx.doi. org/10.1139/z06-134

Matsuoka, S. M., E. M. Bayne, P. Sólymos, P. C. Fontaine, S. G. Cumming, F. K. A. Schmiegelow, and S. J. Song. 2012. Using binomial distance-sampling models to estimate the effective detection radius of point-count surveys across Boreal Canada. Auk 129(2):268-282. http://dx.doi.org/10.1525/ $\underline{\text { auk.2012.11190 }}$

McMaster, D. G., and S. K. Davis. 2001. An evaluation of Canada's permanent cover program: habitat for grassland birds? Journal of Field Ornithology 72:195-210.

Petroleum Resources Branch. 2010. Canadian crude oil, natural gas and petroleum products: review of 2009 \& outlook to 2030. Natural Resources Canada, Ottawa, Ontario, Canada.

R Development Core Team. 2012. R: A language and environment for statistical computing. $\mathrm{R}$ Foundation for Statistical Computing, Vienna, Austria. [online] URL: http:// www.r-project.org/ 
Ranellucci, C. L., N. Koper, and D. C. Henderson. 2012. Twice-over rotational grazing and its impacts on grassland songbird abundance and habitat structure. Rangeland Ecology \& Management 65:109-118. http://dx.doi.org/10.2111/REMD-11-00053.1

Schneider, R. R., J. B. Stelfox, S. Boutin, and S. Wasel. 2003. Managing the cumulative impacts of land uses in the Western Canadian Sedimentary Basin: a modeling approach. Conservation Ecology 7(1): 8. [online] URL: http://www. consecol.org/vol7/iss1/art8

Sólymos, P., S. M. Matsuoka, E. M. Bayne, S. R. Lele, P. Fontaine, S. G. Cumming, D. Stralberg, F. K. A. Schmiegelow, S. J. Song. 2013. Calibrating indices of avian density from non-standardized survey data: making the most of a messy situation. Methods in Ecology and Evolution. http://dx.doi. org/10.1111/2041-210X.12106

Sutter, G. C., S. K. Davis, and D. C. Duncan. 2000. Grassland songbird abundance along roads and trails in southern Saskatchewan. Journal of Field Ornithology 71:110-116.

Tertzakian, P., and K. Baynton. 2011. Turmoil and renewal: the fiscal pulse of the Canadian upstream oil and gas industry, a five year outlook. Arc Financial Corporation and Canadian Association of Petroleum Producers, Calgary, Alberta, Canada.

Thogmartin, W. E. 2010. Sensitivity analysis of North American bird population estimates. Ecological Modelling 221:173-177. http://dx.doi.org/10.1016/j.ecolmodel.2009.09.013

Thogmartin, W. E., F. P. Howe, F. C. James, D. H. Johnson, E. T. Reed, J. R. Sauer, and F. R. Thompson III. 2006. A review of the population estimation approach of the North American Landbird Conservation Plan. Auk 123:892-904. http://dx.doi. org/10.1642/0004-8038(2006)123[892:AROTPE]2.0.CO;2

Timoney, K. P., and P. Lee. 2009. Does the Alberta tar sands industry pollute? The scientific evidence. Open Conservation Biology Journal 3:65-81. http://dx.doi.org/10.2174/1874839200903010065

Timoney, K. P., and R. A. Ronconi. 2010. Annual bird mortality in the bitumen tailings ponds in northeastern Alberta, Canada. Wilson Journal of Ornithology 123:569-576. http:// dx.doi.org/10.1676/09-181.1

Toms, J. D., F. K. A. Schmiegelow, S. J. Hannon, and M.-A. Villard. 2006. Are point counts of boreal songbirds reliable proxies for more intensive abundance estimators? Auk 123:438-454. http://dx.doi.org/10.1642/0004-8038(2006)123 [438:APCOBS]2.0.CO;2

Wayland, M., and J. E. Smits. 2004. The ecological viability of constructed wetlands at Suncor: population and healthrelated considerations in birds. Assessment of natural and anthropogenic impacts of oil sands contaminants within the northern river basins. Final summary report-Task 5: Hydrocarbons/oil sands and heavy oil research and development. Pages 48-57 in F. M. Conly, compiler. Northern Rivers Ecosystem Initiative: collective findings. Environment Canada, Saskatoon, Saskatchewan, Canada.

Wells, J., S. Casey-Lefkowitz, G. Chavarria, and S. Dyer. 2008. Impact on birds of tar sands development in Canada's boreal forest. Natural Resources Defense Council, New York, New York, USA.

Ziff Energy Group. 2003. Western Canada drilling cycle optimization. Ziff Energy Group, Calgary, Alberta, Canada. 


\section{Appendix 1. Summary of data sources and assumption for estimating area disturbed by the oil and gas industry in the Western Canadian Sedimentary Basin during the migratory bird breeding season.}

Table A1.1 Summary of data sources, analyses, functions, and assumptions used to derive estimated area disturbed during the annual breeding season of migratory birds in the Western Canadian Sedimentary Basin by jurisdiction and ecozone.

\begin{tabular}{|c|c|c|c|c|}
\hline Province & Data Source & Functions used & Assumed Width/Size & Seasonality/Area Assumptions \\
\hline \multicolumn{5}{|c|}{ Alberta (Sustainable Resource Development, http://www.altalis.com/prod_base_base.html) } \\
\hline Seismic & SRD Base Layer Database & Buffer analysis & $\begin{array}{l}\text { pre-2005: } 6 \mathrm{~m} \dagger \\
\text { post-2005: } 3.75 \mathrm{~m} \dagger\end{array}$ & $1 \mid-5 \%$ I \\
\hline Pipelines & SRD Base Layer Database & Buffer analysis & $20 \mathrm{~m} \dagger$ & $\begin{array}{l}\text { Distribution: } 1 \% \mid \\
\text { Gathering: Area* } 0.81 * \text { Well assumptions\# }\end{array}$ \\
\hline Wells & SRD Base Layer Database & Buffer analysis & Square ( 2 ha) $\ddagger$ & $\begin{array}{l}\text { Boreal: } 14-18 \% \S \\
\text { Prairie: } 21-27 \% \S\end{array}$ \\
\hline Oil sands & $\begin{array}{l}\text { Gillanders et al. (2008) } \\
\text { Latifovic et al (2005) } \\
\text { Timoney and Lee (2009) }\end{array}$ & see Figure 2 & & Low: $14 \% \dagger \dagger$; High: $33 \%$ †t \\
\hline \multicolumn{5}{|c|}{ British Columbia (Oil and Gas Commission, ftp://www.bcogc.ca/outgoing/OGC_Data/) } \\
\hline Seismic & Geophysical database $\$$ & Buffer analysis & $\begin{array}{l}\text { Buffered using distance } \\
\text { field. Missing values } \\
\text { replaced by weighted } \\
\text { mean }(2.67 \mathrm{~m})\end{array}$ & $1 \mid-5 \%$ II \\
\hline Pipelines & Pipelines database $\$$ & None required & & \\
\hline Wells & Wells database + & Buffer analysis & Square (2 ha) $\ddagger$ & $\begin{array}{l}\text { Boreal: } 14-18 \% \S \\
\text { Prairie: } 21-27 \% \S\end{array}$ \\
\hline
\end{tabular}




\begin{tabular}{|c|c|c|c|c|}
\hline Province & Data Source & Functions used & Assumed Width/Size & Seasonality/Area Assumptions \\
\hline \multicolumn{5}{|c|}{ Manitoba (Innovation Energy and Mines, http://www.gov.mb.ca/iem/petroleum/gis/wells.zip) } \\
\hline Seismic & Model prediction & see Appendix 2 & & $1 \mid-5 \%$ I \\
\hline Pipelines & Model prediction & see Appendix 2 & & $\begin{array}{l}\text { Distribution: } 1 \% \mid \\
\text { Gathering: Area*0.81*Well assumptions\# }\end{array}$ \\
\hline Wells & Wells database & Buffer analysis & Square $(2 \mathrm{ha}) \ddagger$ & $\begin{array}{l}\text { Boreal: } 14-18 \% \S \\
\text { Prairie: } 21-27 \% \S\end{array}$ \\
\hline \multicolumn{5}{|c|}{ Saskatchewan (Energy and Resources, http://www.infomaps.gov.sk.ca/website/SIR_Oil_And_Gas_Wells/viewer.htm) } \\
\hline Seismic & Model prediction & see Appendix 2 & & $1 \mid-5 \%$ I \\
\hline Pipelines & Model prediction & see Appendix 2 & & $\begin{array}{l}\text { Distribution: } 1 \% \mid \\
\text { Gathering: Area*0.81*Well assumptions\# }\end{array}$ \\
\hline Wells & Wells database & Buffer analysis & Square $(2 \mathrm{ha})+$ & $\begin{array}{l}\text { Boreal: } 14-18 \% \S \\
\text { Prairie: } 21-27 \% \S\end{array}$ \\
\hline \multicolumn{5}{|c|}{ SRD Application Disposition Process and Tracking database } \\
\hline \multicolumn{5}{|c|}{ Canadian Association of Petroleum Producers (personal communication), 1 ha for well pad and 1 ha for associated access } \\
\hline \multicolumn{5}{|c|}{$\begin{array}{l}\text { Based proportion of annual wells completed during breeding season of May-July (Boreal) and April-July (Prairie) from monthly } \\
\text { well count data (http://www.caodc.ca/statistics/wellcounts_wc_monthly.html) }\end{array}$} \\
\hline \multicolumn{5}{|c|}{ Canadian Association of Petroleum Producers (personal communication) } \\
\hline \multicolumn{5}{|c|}{$\begin{array}{l}20 \% \text { of seismic exploration is conducted outside of winter period (Ziff Energy Group 2003) and assumed 25\% of this occurs during } \\
\text { the breeding season }\end{array}$} \\
\hline \multicolumn{5}{|c|}{$\begin{array}{l}\text { Total pipeline area } * 0.81(\sim 81 \% \text { gathering lines }) * \text { proportion of clearing assumed for Well seasonality (since new wells must be } \\
\text { connected to distribution network) }\end{array}$} \\
\hline \multicolumn{5}{|c|}{$\dagger \dagger$ Based upon well site data (low) } \\
\hline
\end{tabular}




\section{LITERATURE CITED}

Gillanders, S. N., N. C. Coops, M. A. Wulder, and N. R. Goodwin. 2008. Application of Landsat satellite imagery to monitor land-cover changes at the Athabasca Oil Sands, Alberta, Canada. The Canadian Geographer 52:466-485.

Latifovic, R., K. Fytas, J. Chen, and J. Paraszczak. 2005. Assessing land cover change resulting from large surface mining development. International Journal of Applied Earth Observation and Geoinformation 7:29-48.

Timoney, K. P., and P. Lee. 2009. Does the Alberta tar sands industry pollute? The scientific evidence. The Open Conservation Biology Journal 3:65-81. 


\section{Appendix 2. Statistical models to estimate footprint of seismic lines and pipelines for jurisdictions in the Western Canadian Sedimentary Basin lacking geo-referenced data.}

\section{SUPPLEMENTAL METHODS}

Data from Alberta Sustainable Resource Development (Appendix 1) were summarized using GIS to calculate density of wells (wells/ $\mathrm{km}^{2}$ ) and area disturbed (as proportion of township) by seismic lines and pipelines respectively within townships across Alberta. General linear modeling (GLM) was subsequently used to model proportion of a township disturbed by seismic lines and pipelines as a function of well densities. Prior to analysis, well densities (hereafter $\log ($ wells $)$ ) were transformed using $\log _{10}(\mathrm{x}+0.5)$ to meet the assumptions for GLM. Similarly, both the proportion of a township disturbed by seismic lines and the proportion of a township disturbed by pipelines were square root transformed prior to analysis. For both response variables, three competing models models were considered; i.e. $\log ($ wells $), \log ($ wells $)+$ Natural Region, and $\log ($ wells $)+$ Natural Region $+\log (\text { wells })^{*}$ Natural Region. The model with the lowest AIC (Akaike's Information Criterion) score was subsequently selected as the most parsimonious model (Burnham and Anderson 1998).

\section{RESULTS}

Data from 7115 townships in Alberta were summarized. Well densities averaged 0.53 wells $/ \mathrm{km}^{2}$ (median $=0.22$, range $=0-10.36$ ). An average of $0.76 \%$ of township area was disturbed by seismic lines (median $=0.48$, range $=0-12.08$ ). Pipeline right-of-ways made up an average of $0.59 \%$ of township area (median $=0.25$, range $=0-8.68$ ).

The most parsimonious model for proportion of townships disturbed by seismic lines included $\log$ (wells), Natural Region and the interaction between Natural Region and $\log$ (wells) and was separated from the next best model by over 298 AIC units. The top model explained $\sim 31 \%$ of the variance in proportion of townships disturbed by seismic lines. Based on the parameter estimates (Table A.2.1), the derived equation for estimating the proportion of township disturbed by seismic lines in the Boreal Plain ecozone can be estimated as:

$\%$ of township disturbed by seismic $=(0.974+0.807 * \log (\text { wells }))^{2}$

The parameter estimates suggest that given an equal density of wells, the area disturbed by seismic lines is lower in the Grassland Natural Region than the Boreal ecozone (Table A2.1). The proportion of a township disturbed by seismic lines in the Grassland Natural Region can be estimated as:

$\%$ of township disturbed by seismic $=(0.430+0.006 * \log (\text { wells }))^{2}$

The most parsimonious model for the proportion of townships disturbed by pipeline right-ofways also included $\log$ (wells), Natural Region and the interaction between Natural Region and $\log$ (wells). The top model was separated from the next best model by over 798 AIC units, and explained $\sim 63 \%$ of the variance in proportion of townships disturbed by pipeline right-of-ways. Based on the parameter estimates (Table A2.2), the proportion of a township disturbed by pipeline right-of-ways in the Boreal Plain ecozone can be estimated as:

$\%$ of township disturbed by pipeline $=(0.699+1.866 * \log (\text { wells }))^{2}$ 
Similar to the analysis for seismic lines, the parameter estimates suggest that given equivalent well densities, the area disturbed by pipeline right-of-ways is higher in the Boreal ecozone than the Grassland Natural Region (Table A2.2). Using parameter estimates reported in Table 2, the proportion of a township disturbed by pipeline right-of-ways in the Grassland Natural Region can be estimated as:

$\%$ of township disturbed by pipeline $=(0.655+1.811 * \log (\text { wells }))^{2}$

Table A.2.1. Parameter estimates for predicting proportion of townships disturbed by seismic lines. Note: the predictions must by squared due to square root transformation of the response variable prior to analysis.

\begin{tabular}{lllrc}
\hline \hline Parameter & $\beta$ & SE & \multicolumn{1}{c}{ t- value } & \multicolumn{1}{c}{$\mathrm{P}$} \\
\hline Intercept & 0.947 & 0.008 & 125.438 & $<0.001$ \\
$\log ($ Wells $)$ & 0.807 & 0.032 & 25.282 & $<0.001$ \\
Foothills & 0.201 & 0.017 & 12.076 & $<0.001$ \\
Grassland & -0.517 & 0.016 & -32.602 & $<0.001$ \\
Parkland & -0.475 & 0.020 & -23.872 & $<0.001$ \\
Rocky Mountain & 0.243 & 0.089 & 2.730 & $<0.001$ \\
$\log ($ Wells):Foothills & -0.371 & 0.085 & -4.352 & $<0.001$ \\
$\log ($ Wells):Grassland & -0.801 & 0.054 & -14.730 & $<0.001$ \\
$\log ($ Wells):Parkland & -0.701 & 0.076 & -9.206 & $<0.001$ \\
$\log ($ Wells): Rocky Mountain & 2.131 & 0.312 & 6.840 & $<0.001$ \\
\hline
\end{tabular}

Table A2.2. Parameter estimates for predicting proportion of townships disturbed by pipeline right-of-ways. Note: the predictions must by squared due to square root transformation of the response variable prior to analysis.

\begin{tabular}{lccrc}
\hline \hline Parameter & $\beta$ & SE & t- value & P \\
\hline Intercept & 0.699 & 0.006 & 109.097 & $<0.001$ \\
$\log ($ Wells $)$ & 1.866 & 0.027 & 68.918 & $<0.001$ \\
Foothills & 0.208 & 0.014 & 14.681 & $<0.001$ \\
Grassland & -0.044 & 0.013 & -3.275 & $<0.05$ \\
Parkland & -0.046 & 0.017 & -2.734 & $<0.05$ \\
Rocky Mountain & 0.405 & 0.076 & 5.370 & $<0.001$ \\
$\log$ (Wells):Foothills & 0.459 & 0.072 & 6.336 & $<0.001$ \\
$\log$ (Wells):Grassland & -0.055 & 0.046 & -1.200 & 0.230 \\
$\log$ (Wells):Parkland & -1.689 & 0.065 & -26.128 & $<0.001$ \\
$\log$ (Wells):Rocky Mountain & 1.644 & 0.264 & 6.218 & $<0.001$ \\
\hline
\end{tabular}

\section{LITERATURE CITED}

Burnham, K.P., and D. R. Anderson. 1998. Model Selection and Inference: A Practical Information-Theoretic Approach. Springer-Verlag, New York, NY, USA, 353 pp. 